\title{
Prediksi Kualitas Pelayanan Dan Kepercayaan Terhadap Loyalitas Pelanggan: Kepuasan Pelanggan Sebagai Variabel Mediasi
}

\author{
Juliana dan Keni \\ Program Studi Manajemen, Fakultas Ekonomi, Universitas Tarumanagara, Jakarta \\ Email: julianalina1997@gmail.com, keni@fe.untar.ac.id.
}

\begin{abstract}
The purpose of this research is to examine whether 1) service quality and trust can predict customer loyalty, 2) servie quality and trust can predict customer satisfaction, 3) customer satisfaction can predict customer loyalty and 4) customer satisfaction can mediate service quality and trust on customer loyalty. The samples are 153 respondents by online questionnaires with the nonprobability sampling technique with convenience sampling. Overall, the result of this study are 1) service quality and trust can not positively and significantly predict customer loyalty, 2) service quality and trust can positively and significantly predict customer satisfaction, 3) customer satisfaction can positively and significantly predict customer loyalty, 4) customer satisfaction can mediate the positive prediction of service quality and trust on customer loyalty.
\end{abstract}

Keywords: Service Quality, Trust, Customer Satisfaction, Customer Loyalty

Abstrak: Tujuan dari penelitian ini adalah untuk menguji apakah 1) kualitas pelayanan dan kepercayaan dapat memprediksi loyalitas pelanggan, 2) kualitas pelayanan dan kepercayaan dapat memprediksi kepuasan pelanggan, 3) kepuasan pelanggan dapat memprediksi loyalitas pelanggan dan 4) kepuasan pelanggan dapat memediasi kualitas layanan dan kepercayaan pada loyalitas pelanggan. Sampel penelitian adalah 153 responden dengan kuesioner online dengan teknik nonprobability sampling dengan convenience sampling. Secara keseluruhan, hasil penelitian ini adalah 1) kualitas layanan dan kepercayaan tidak dapat secara positif dan signifikan memprediksi loyalitas pelanggan, 2) kualitas layanan dan kepercayaan dapat memprediksi secara positif kepuasan pelanggan, 3) kepuasan pelanggan dapat secara positif dan signifikan memprediksi loyalitas pelanggan, 4) kepuasan pelanggan dapat memediasi prediksi positif kualitas layanan dan kepercayaan terhadap loyalitas pelanggan.

Kata Kunci: Kualitas Pelayanan, Kepercayaan, Kepuasan Pelanggan, Loyalitas Pelanggan

\section{LATAR BELAKANG}

Pertumbuhan ekonomi adalah proses perubahan kondisi perekonomian suatu negara secara berkesinambungan menuju keadaan yang lebih baik selama periode tertentu. Pertumbuhan ekonomi suatu negara dapat ditandai dengan pertumbuhan industri perbankan yang ada dalam negara tersebut. Menurut Idun dan Aboagye (2014) tingkat persaingan bank menunjukkan efek positif pada pertumbuhan ekonomi dalam jangka panjang. 
Loyalitas pelanggan dianggap memainkan peran penting dalam mempertahankan penjualan dan meningkatkan laba (Lai et al., 2009). Biaya yang terlibat dalam memperoleh pelanggan baru dianggap jauh lebih besar daripada melayani, dan mempertahankan pelanggan yang sudah ada, memerlukan strategi untuk mempertahankan loyalitas pelanggan (Liang et al., 2013). Namun, loyalitas pelanggan adalah konsep yang kompleks, dipicu oleh sejumlah faktor pendahulunya.

Untuk bertahan di pasar yang kompetitif perusahaan harus terus meningkatkan kinerja layanannya (Kim et al., 2007). Menurut Makanyeza dan Chikazhe (2017) kualitas pelayanan, kepuasan pelanggan dan citra perusahaan memiliki efek yang positif terhadap loyalitas pelanggan. Sementara hasil penelitian Boonlertvanich (2019) menjelaskan bahwa kepercayaan yang lebih tinggi mengarah pada sikap dan perilaku loyalitas yang lebih tinggi juga. Yap, Ramayah, dan Shahidan (2012) juga menyatakan kepercayaan dan kepuasan memiliki efek yang positif terhadap loyalitas pelanggan.

Hasil penelitian Boonlertvanich (2019) menjelaskan bahwa kualitas pelayanan secara langsung mempengaruhi loyalitas pelanggan dan secara tidak langsung melalui kepuasan pelanggan. Loyalitas pelanggan suatu perusahaan akan meningkat lebih signifikan jika perusahaan tersebut dapat terlebih dahulu meningkatkan kepercayaan pelanggannya (Fauzi \& Suryani, 2019). Sementara penelitian Saputra dan Dewi (2015) membuktikan bahwa kepercayaan adalah prediktor terhadap loyalitas pelanggan dengan kepuasan pelanggan sebagai mediator.

Tujuan penelitian ini untuk mengetahui apakah kualitas pelayanan dan kepercayaan dapat memprediksi loyalitas pelanggan, apakah kualitas pelayanan dan kepercayaan dapat memprediksi kepuasan pelanggan, apakah kepuasan pelanggan dapat memprediksi loyalitas pelanggan, apakah kepuasan pelanggan dapat memediasi prediksi kualitas pelayanan dan kepercayaan terhadap loyalitas pelanggan.

\section{KAJIAN TEORI}

\section{Kualitas Pelayanan}

Menurut Parasuraman, Berry dan Zeithaml (1988: 12) "Quality of a service depends on the service provider's ability to consistently meet the needs and desires of consumers". Sementara Kotler dan Armstrong (2010: 38) menyatakan "Service quality as the customer's judgement about an entity's overall excellence or superiority and suggest that perceived quality". Chenet, Dagger dan O'Sullivan (2010: 337) menjelaskan kualitas pelayanan adalah: "service quality as the customer's evaluation of the standard of service received across the domains of reliability, responsiveness, and empathy". Berdasarkan definisi di atas dapat disimpulkan bahwa kualitas pelayanan adalah penilaian atau evaluasi pelanggan terhadap standar layanan yang diberikan penyedia layanan untuk secara konsisten dapat memenuhi kebutuhan dan keinginan pelanggan.

Menurut Parasuraman, Zeithaml dan Berry (1988) kualitas pelayanan dapat dilihat dari lima dimensi pokok, yaitu:

a. Bukti fisik (tangible), yaitu kemampuan suatu perusahaan dalam menunjukkan

eksistensinya kepada pesaingnya. Penampilan dan kemampuan, sarana dan prasarana fisik

perusahaan yang dapat diandalkan merupakan bukti nyata dari pelayanan yang diberikan 
oleh pemberi layanan.

b. Keandalan (reliability), yaitu kemampuan perusahaan untuk memberikan pelayanan sesuai

yang dijanjikan secara akurat, tepat waktu dan terpercaya.

c. Daya tanggap (responsiveness), yaitu suatu keinginan untuk membantu dan memberikan pelayanan yang cepat dan tepat kepada pelanggan, disertai penyampaian informasi yang

jelas.

d. Jaminan dan kepastian (assurance), yaitu pengetahuan, kesopanan, dan kemampuan para

pegawai perusahaan untuk menumbuhkan rasa percaya para pelanggan kepada perusahaan.

Hal ini meliputi komunikasi, kredibilitas, keamanan, kompetensi, dan sopan santun.

e. Empati (empathy), yaitu memberikan perhatian yang tulus dan bersifat individual atau pribadi yang diberikan kepada para pelanggan dengan berupaya memahami keinginan konsumen.

\section{Kepercayaan}

Moorman, Zaltman dan Deshpande (1992: 315) menyatakan: "trust is defined as a willingness to rely on an exchange partner in whom one has confidence". Sementara Doney, Cannon dan Mullen (1998: 604) menjelaskan: "trust is a willingness to rely on another party and to take action in circumstances where such action makes one vulnerable to the other party". Lebih lanjut Orth dan Green (2009: 249) menyatakan: "trust as the expectation held by the consumer that the service provider is dependable and can be relied on to deliver on its promises". Berdasarkan definisi dari para ahli di atas, dapat disimpulkan bahwa kepercayaan adalah kesediaan seseorang untuk menggantungkan harapannya pada pihak lain yang dapat diandalkan untuk mengambil tindakan dalam situasi di mana tindakan tersebut membuat seseorang rentan.

\section{Loyalitas Pelanggan}

Oliver (1999: 34) menjelaskan loyalitas pelanggan adalah: " $a$ deeply held commitment to rebuy or patronize a preferred product or service consistently in the future, thereby causing repetitive same-brand or same brand-set purchasing, despite situational influences and marketing efforts having the potentional to cause switching behavior". Sementara Hur et al. (2010: 2296) mendefinisikan loyalitas sebagai: "the continuous repurchase of (or ongoing supporting behavior towards) a preferred product or service, regardless of other options and/or marketing efforts to induce switching to competitors". Lebih lanjut Bouranta, Psomas dan Vouzas (2019: 73) mendefinisikan loyalitas sebagai: "... positive feelings toward a product and dedication to purchase the same product repeatedly regardless of a competitor's actions or changes in the environment". Berdasarkan definisi dari para ahli di atas, dapat disimpulkan bahwa loyalitas pelanggan adalah komitmen yang dipegang teguh untuk melakukan pembelian berulang kali atau berlangganan layanan yang disukai secara konsisten di masa depan, meskipun pengaruh situasional dan upaya pemasaran dapat memiliki potensi peralihan perilaku. 


\section{Kepuasan Pelanggan}

Mano dan Oliver (1993: 454) mengungkapkan customer satisfaction adalah "essence an overall post-consumption evaluation from the customer's point-of-view". Oliver (1999: 34) menyatakan customer satisfaction adalah "the consumer's sense that consumption provides outcomes against a standard of pleasure versus displeasure”. Sementara menurut Eid (2015: 252) “....consumer satisfaction as a consumer's overall emotional response to the entire service experience for a single transaction at the post purchasing point". Berdasarkan definisi dari para ahli di atas, dapat disimpulkan bahwa kepuasan pelanggan adalah respon positif yang dirasakan oleh pelanggan pasca pengalaman pembelian dan penggunaan layanan.

\section{Kaitan Antara Kualitas Pelayanan, Kepercayaan dan Loyalitas Pelanggan}

Stan et al. (2013) mengemukakan bahwa loyalitas pelanggan kepada peursahaan didorong oleh interaksi berbagai faktor yang dimulai dengan persepsi pelanggan tentang kualitas pelayanan yang ditawarkan oleh perusahaan berdasarkan pengalaman pertama. Menurut Zeithaml, Berry dan Parasuraman (1996) kualitas pelayanan berpengaruh positif tehadap loyalitas pelanggan. Hal tersebut diperkuat oleh hasil penelitian Makanyeza dan Chikazhe (2017) : 548) yang menyatakan: bahwa kualitas pelayanan, kepuasan pelanggan, dan citra perusahaan memiliki efek yang positif secara langsung terhadap loyalitas pelanggan.

Cho dan $\mathrm{Hu}$ (2009) menjelaskan bahwa kepercayaan meningkatkan kemauan konsumen untuk kembali melakukan transaksi di masa depan dan meningkatkan kemungkinan merekomendasikan perusahaan kepada konsumen lain. Hasil penelitian oleh Plasmeijer dan Raaij (2017), Fauzi dan Suryani (2019), dan Bonlertvanich (2019) menunjukkan bahwa terdapat hubungan positif antara kepercayaan dengan loyalitas pelanggan. Penelitian yang dilakukan oleh Plasmeijer dan Raaij (2017) membuktikan bahwa kepercayaan adalah prediktor kuat kesetiaan. Hasil penelitian tersebut juga diperkuat oleh hasil penelitian Fauzi dan Suryani yang menjelaskan bahwa loyalitas pelanggan akan meningkat lebih signifikan jika perusahaan dapat meningkatkan kepercayaan pelanggannya terlebih dahulu. Berdasarkan uraian di atas, maka hipotesis pertama adalah:

H1a: Kualitas pelayanan dapat memprediksi secara positif loyalitas pelanggan.

H1b: Kepercayaan dapat memprediksi secara positif loyalitas pelanggan.

\section{Kaitan Antara Kualitas Pelayanan, Kepercayaan dan Kepuasan Pelanggan}

Kualitas pelayanan dan kepuasan pelanggan adalah dua konsep inti pada pusat teori dan praktik pemasaran (Spreng \& Mackoy, 1996). Kepuasan pelanggan terletak pada seberapa baik suatu layanan dapat memenuhi dan melampaui harapan pelanggan dan karenanya pelanggan menilai kinerja perusahaan (Parasuraman et al., 2005). Jika pelanggan puas dengan layanan yang dirasakan, sikap pelanggan terhadap perusahaan akan meningkat, dan sikap ini akan menghasilkan kepuasan pelanggan terhadap perusahaan (Andreassen \& Lindestad, 1998). Hasil penelitian Awan, Bukhari dan Iqbal (2011) memvalidasi aspek kualitas pelayanan untuk kepuasan pelanggan. Hasil penelitian Shafei dan Tabaa (2016) juga telah membuktikan bahwa tingkat kualitas pelayanan yang tinggi berkaitan dengan kepuasan pelanggan yang lebih tinggi. 
Dalam bisnis, kepercayaan dipandang sebagai salah satu faktor pendahulu yang paling relevan dari hubungan yang stabil dan kolaboratif (Kundu \& Datta, 2015). Hasil penelitian Kundu dan Datta (2015) juga telah membuktikan bahwa kepercayaan mempengaruhi kepuasan pelanggan secara langsung. Pernyataan tersebut diperkuat oleh penelitian yang dilakukan oleh Fatima dan Razzaque (2014) yang membuktikan bahwa kepercayaan memiliki dampak yang signifikan terhadap kepuasan. Fatima dan Razzaque (2014) menyarankan kepada manajer yang bersedia membangun hubungan dengan pelanggan yang puas dengan harus fokus pada kepercayaan. Berdasarkan uraian di atas, maka hipotesis kedua adalah:

H2a: Kualitas Pelayanan dapat memprediksi secara positif kepuasan pelanggan.

$\mathrm{H} 2 \mathrm{~b}$ : Kepercayaan dapat memprediksi secara positif kepuasan pelanggan.

\section{Kaitan Antara Kepuasan Pelanggan dengan Loyalitas Pelanggan}

Loyalitas pelanggan adalah konstruk yang banyak dipelajari dalam riset pemasaran (Makanyeza \& Chikazhe, 2017). Ketika pelanggan puas cenderung untuk membeli kembali produk atau layanan yang mengarah pada peningkatan loyalitas (Johnson et al., 2001). Dalam penelitian Sheng dan Liu (2010) membuktikan bahwa loyalitas pelanggan dipengaruhi secara positif oleh kepuasan pelanggan. Hal ini didukung oleh penelitian Shafei dan Tabaa (2016) yang menyatakan bahwa loyalitas pelanggan juga dipengaruhi oleh kepuasan pelanggan. Hasil penelitian Ram dan Wu (2016) juga telah membuktikan bahwa kepuasan pelanggan memiliki hubungan langsung dan positif dengan loyalitas pelanggan. Berdasarkan uraian di atas, maka hipotesis ketiga adalah:

H3: Kepuasan pelanggan dapat memprediksi secara positif loyalitas pelanggan.

\section{Kepuasan Pelanggan Memediasi Kaitan antara Kualitas Pelayanan, Kepercayaan dan Loyalitas Pelanggan}

Penelitian Boonlertvanich (2019) menunjukkan bahwa kualitas layanan memiliki pengaruh tidak langsung yang signifikan terhadap loyalitas, melalui kepuasan. Penelitian yang dilakukan oleh Yunus, Ibrahim dan Amir (2018) juga membuktikan bahwa kepuasan pelanggan berperan sebagai mediasi antara kualitas pelayanan dengan loyalitas pelanggan. Dengan demikian, kualitas pelayanan merupakan salah satu penentu utama keberhasilan dalam menciptakan kepuasan pelanggan yang kemudian mempengaruhi loyalitas pelanggan (Kuo et al., 2011).

Hasil penelitian Saputra dan Dewi (2015) menunjukkan bahwa kepercayaan secara signifikan mempengaruhi kepuasan, artinya pelanggan percaya bahwa perusahaan tersebut aman dan akrab dengan pelanggann. Swidi et al. (2013) menyatakan kepuasan dianggap sebagai variabel mediasi antara kepercayaan dengan loyalitas pelanggan. Temuan ini juga menunjukkan bahwa kepuasan dapat memainkan peran intervensi penting dalam hubungan kepercayaan dengan loyalitas. Dengan demikian, konsep kepercayaan dan kepuasan pelanggan saling melengkapi (Swidi et al., 2013). Berdasarkan uraian di atas, maka hipotesis keempat adalah:

H4a: Kepuasan pelanggan dapat memediasi prediksi secara positif kualitas pelayanan terhadap loyalitas pelanggan

$\mathrm{H} 4 \mathrm{~b}$ : Kepuasan pelanggan dapat memediasi prediksi secara positif kepercayaan terhadap loyalitas pelanggan. 
Berdasarkan uraian kaitan antar variabel di atas, maka model penelitian adalah sebagai berikut:

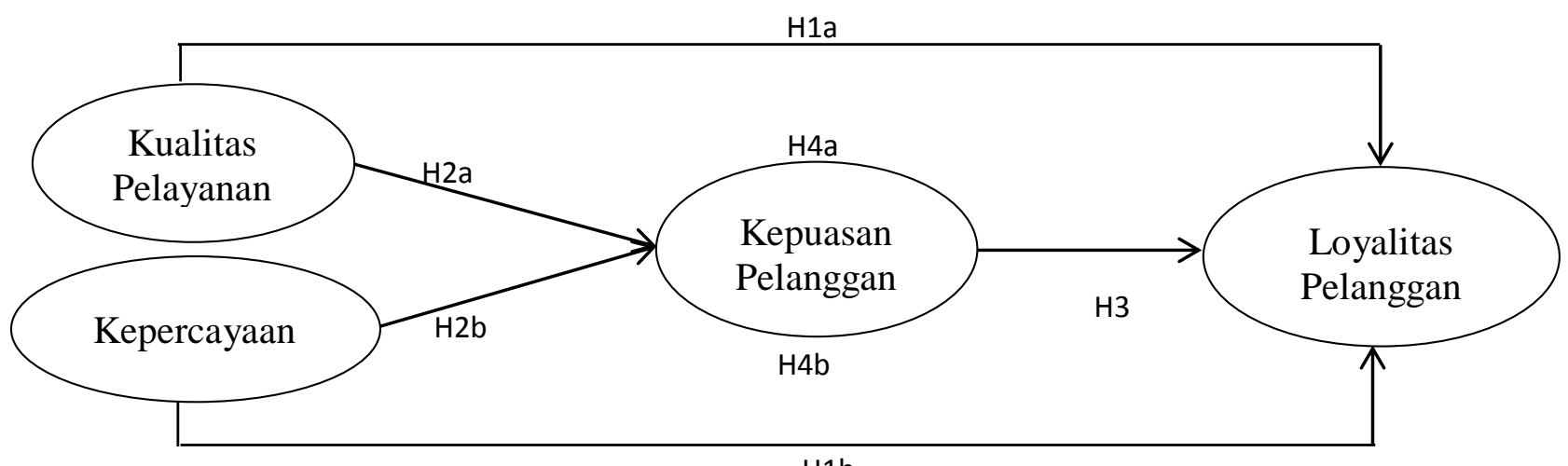

Gambar 1. Model Penelitian

\section{METODELOGI}

Desain penelitian pada penelitian ini menggunakan desain penelitian deskriptif dengan metode cross sectional design. Populasi dalam penelitian adalah seluruh pelanggan di Jakarta. Metode pengambilan sampel yang digunakan adalah non-probability sampling dengan teknik convenience sampling yang artinya tidak semua pelanggan akan dijadikan sampel. Dalam teknik ini, responden dipilih karena telah memenuhi kriteria penelitian dan kemudahan untuk dijangkau oleh peneliti. Responden yang dapat dijadikan sampel adalah seorang yang sudah menjadi nasabah bank lebih dari satu tahun.

Sampel dalam penelitian ini sebesar 153 responden. Berdasarkan data yang telah dikumpulkan, diketahui bahwa mayoritas berjenis kelamin perempuan dan sebesar 147 orang atau sebesar $96 \%$ berusia 17 hingga 27 tahun. Responden pada penelitian ini, sebesar 118 orang atau sebesar $77 \%$ berdomisili di Jakarta dan sebesar 55\% berpendidikan terakhir S1/S2/S3. Mayoritas responden adalah pelajar atau mahasiswa yaitu sebanyak 117 orang (77\%) dan sebesar 66\% berpendapatan Rp 1.000.000 hingga Rp 4.000.000 perbulannya. Responden dalam penelitian ini juga menjadi pelanggan lembaga keuangan lainnya.

Instrumen diadaptasi dari penelitian terdahulu untuk mengukur variabel penelitian seperti yang tertera di Tabel 1 dengan menggunakan skala Likert lima poin dengan 1 menunjukan "sangat tidak setuju" dan 5 menunjukan "sangat setuju". Tabel 1 menunjukan pengukuran masing-masing variabel dan sumbernya, instrumen tersebut telah dilakukan analisis validitas dengan hasil analisis convergent validity yaitu nilai loading factor seluruh indikator seluruh variabel menunjukan hasil diatas 0,7 dan nilai AVE seluruh variabel lebih besar dari 0,5 (Henseler et al. 2009). Kemudian untuk analisis discriminant validity menunjukan nilai cross loading tiap indikator variabelnya lebih besar dari korelasi antar variabel lainnya dan analisis fornell-larcker menunjukan nilai akar kuadrat AVE lebih besar dari korelasi antar variabel lainnya sehingga seluruh instrumen dinyatakan valid (Henseler et al. 2009). Sementara untuk analisis reliabilitas didasarkan pada nilai cronbach's alpha dan composite reliability yang masing masing hasilnya menunjukan nilai lebih dari 0,6 sehingga semua indikator dalam penelitian adalah reliable (Maholtra, 2009). 
Tabel 1. Variabel data Pengukuran

\begin{tabular}{|l|c|c|}
\hline \multicolumn{1}{|c|}{ Variabel } & Jumlah Item & Sumber \\
\hline Variabel Bebas & 25 & Chenet, Dagger dan O'Sullivan \\
1. Kualitas Pelayanan & 5 & (2010) \\
2. Kepercayaan & & $\begin{array}{c}\text { Levesque dan McDougall (1996) } \\
\text { Fauzi dan Suryani (2019) } \\
\text { Boonlertvanich (2019) } \\
\text { Ndubisi (2007) }\end{array}$ \\
\hline $\begin{array}{l}\text { Variabel Terkait } \\
\text { Loyalitas Pelanggan }\end{array}$ & 6 & $\begin{array}{c}\text { Sheng dan Liu (2010) } \\
\text { Ndubisi (2007) } \\
\end{array}$ \\
\hline $\begin{array}{c}\text { Variabel Mediasi } \\
\text { Kepuasan Pelanggan (2017) }\end{array}$ & & $\begin{array}{c}\text { Sheng dan Liu (2010) } \\
\text { Shi } \text { et al. (2016) }\end{array}$ \\
\hline
\end{tabular}

\section{Hasil Uji Statistik}

Hasil analisis data secara singkat tertera pada Tabel 2. berikut ini:

Tabel 2. Hasil Pengujian Hipotesis

\begin{tabular}{llcc}
\hline & \multicolumn{1}{c}{ Hipotesis } & Coefficient & t-statistic \\
\hline H1a & Kualitas Pelayanan -> Loyalitas Pelanggan & 0,224 & 1,746 \\
\hline H1b & Kepercayaan -> Loyalitas Pelanggan & 0,128 & 1,177 \\
\hline H2a & Kualitas Pelayanan -> Kepuasan Pelanggan & 0,556 & $5,399^{* *}$ \\
\hline H2b & Kepercayaan -> Kepuasan Pelanggan & 0,321 & $2,978^{* *}$ \\
\hline H3 & Kepuasan Pelanggan -> Loyalitas Pelanggan & 0,521 & $4,675^{* *}$ \\
\hline H4a & $\begin{array}{l}\text { Kualitas Pelayanan -> Kepuasan Pelanggan - } \\
\text { > Loyalitas Pelanggan }\end{array}$ & 0,290 & $3,515^{* *}$ \\
\hline H4b & $\begin{array}{l}\text { Kepercayaan -> Kepuasan Pelanggan -> } \\
\text { Loyalitas Pelanggan }\end{array}$ & 0,167 & $2,437^{*}$ \\
\hline
\end{tabular}

$* \mathrm{p}<0,05 ; * * \mathrm{p}<0,01$

Suatu model dapat diterima jika dari adanya hubungan pengaruh tersebut lebih tinggi dari nilai signifikansi (t-statistics $>1,96 ; \alpha=5 \%$ ). Berdasarkan nilai $t$-statistic pada Tabel $2 \mathrm{di}$ atas maka dapat disimpulkan bahwa hipotesis pertama ditolak dengan nilai $t$-statistic sebesar 1,746 dan 1,177. Pada hipotesis kedua tidak ditolak karena hasil nilai t-statistic sebesar 5,399 dan 2,978. Lebih lanjut, hipotesis ketiga pada penelitian ini tidak ditolak dengan nilai $t$-statistics sebesar 4,675. Dan pada hipotesis keempat memiliki nilai $t$ statistic sebesar 3,515 dan 2,437, maka hipotesis keempat tidak ditolak.

\section{DISKUSI}

Berdasarkan hasil rekapitulasi pengujian hipotesis pertama, variabel kualitas pelayanan terbukti tidak mampu memprediksi secara positif loyalitas pelanggan. Hasil penelitian ini tidak sesuai dengan penelitian terdahulu yang telah dilakukan oleh Al Rousan et al. (2010), Makanyeza dan Chikazhe (2017), dan Boonlertvanich (2019), dimana hasil penelitian tersebut mendukung hubungan positif antara kualitas pelayanan dengan loyalitas pelanggan. Hasil penelitian yang berbeda dilakukan oleh Solimun dan 
Fernandes (2018) menemukan bahwa kualitas pelayanan tidak memiliki pengaruh secara langsung terhadap loyalitas pelanggan, namun menemukan pengaruh yang signifikan apabila melalui mediator kepuasan pelanggan. Hasil penelitian Solimun dan Fernandes (2018) sejalan dengan hasil penelitian ini yang menemukan bahwa kualitas pelayanan tidak dapat memprediksi secara positif loyalitas pelanggan. Stan et al. (2013) mengemukakan bahwa loyalitas pelanggan kepada perusahaan didorong oleh interaksi berbagai faktor yang dimulai dengan persepsi pelanggan tentang kualitas pelayanan yang ditawarkan berdasarkan pengalaman pertama.

Hasil pengujian hipotesis 1b menunjukkan bahwa variabel kepercayaan juga tidak terbukti mampu memprediksi loyalitas pelanggan. Hasil penelitian ini tidak sejalan dengan penelitian sebelumnya yang telah dilakukan oleh Plasmeijer dan Raaij (2017), Fauzi dan Suryani (2019), dan Bonlertvanich (2019) yang menemukan bahwa terdapat hubungan yang positif antara kepercayaan dengan loyalitas pelanggan. Namun hasil penelitian ini sesuai dengan penelitian yang dilakukan oleh Tabrani, Amin, dan Nizam (2018) yang menemukan bahwa kepercayaan tidak memiliki hubungan positif terhadap loyalitas pelanggan secara langsung, tetapi memiliki hubungan positif terhadap loyalitas pelanggan melalui mediasi, yaitu komitmen dan keintiman.

Selanjutnya, hasil rekapitulasi pengujian hipotesis kedua, variabel kualitas pelayanan terbukti mampu memprediksi kepuasan pelanggan. Hasil penelitian ini sejalan dengan penelitian yang telah dilakukan oleh Awan, Bukhari dan Iqbal (2011), Shafei dan Tabaa (2016), dan Boonlertvanich (2019) yang mendukung hubungan positif antara kualitas pelayanan dengan kepuasan pelanggan. Kepuasan pelanggan terletak pada seberapa baik suatu layanan dapat memenuhi dan melampaui harapan pelanggan dan karenanya pelanggan menilai kinerja perusahaan (Parasuraman et al., 2005). Hasil penelitian ini juga sejalan dengan teori Kotler dan Keller (2012) yang menyatakan bahwa kepuasan juga akan tergantung pada kualitas layanan dan tingkat kualitas yang lebih tinggi akan menghasilkan tingkat kepuasan pelanggan yang lebih tinggi juga.

Hasil pengujian hipotesis $2 \mathrm{~b}$, variabel kepercayaan terbukti dapat memprediksi kepuasan pelanggan. Hasil ini sesuai dengan penelitian sebelumnya yang dilakukan oleh Kundu dan Datta (2015); Fatima dan Razzaque (2014) yang membuktikan bahwa kepercayaan memiliki dampak yang signifikan terhadap kepuasan. Kepercayaan secara logis dan eksperimental merupakan variabel penting dalam hubungan (Moorman et al., 1993).

Berdasarkan hasil rekapitulasi pengujian hipotesis ketiga, variabel kepuasan pelanggan terbukti mampu memprediksi secara positif loyalitas pelanggan. Hasil pada penelitian ini sejalan dengan penelitian yang telah dilakukan sebelumnya oleh Sheng dan Liu (2010), Shafei dan Tabaa (2016), dan Ram dan Wu (2016) yang membuktikan bahwa loyalitas pelanggan dipengaruhi secara positif oleh kepuasan pelanggan. Johnson et al. (2001) juga menyatakan bahwa ketika pelanggan puas cenderung untuk membeli kembali produk atau layanan ang mengarah pada peningkatan kualitas.

Terakhir, hasil rekapitulasi pengujian hipotesis keempat, kepuasan pelanggan mampu memediasi prediksi secara positif kualitas pelayanan terhadap loyalitas pelanggan. Hasil ini sesuai dengan penelitian terdahulu oleh Yunus, Ibrahim dan Amir (2018) dan Boonlertvanich (2019) yang menyatakan menunjukkan bahwa kualitas layanan memiliki pengaruh tidak langsung yang signifikan terhadap loyalitas, melalui kepuasan. Kuo et al. (2011) juga menyatakan bahwa kualitas pelayanan merupakan salah satu penentu utama 
keberhasilan dalam menciptakan kepuasan pelanggan yang kemudian mempengaruhi loyalitas pelanggan. Hasil penelitian ini sejalan dengan penelitian yang dilakukan oleh Saputra dan Dewi (2015) yang menunjukkan bahwa jika perusahaan ingin pelanggan setia, maka harus membuat layanan yang dipercaya oleh pelanggan, sehingga pelanggan tersebut akan puas dan kemudian menjadi pelanggan yang setia.

\section{PENUTUP}

\section{Simpulan}

Kualitas pelayanan yang ditawarkan oleh lembaga perbankan adalah salah satu kriteria yang yang menentukan pilihan pelanggan terhadap bank. Tetapi bank tidak dapat menjadikan konsumen setia hanya dengan memberikan kualitas pelayanan yang baik namun juga dengan memperhatikan berbagai faktor lainnya. Kepercayaan meningkatkan kemauan konsumen untuk kembali melakukan transaksi di masa depan dan meningkatkan kemungkinan merekomendasikan bank kepada konsumen lain. Akibatnya, tingkat kualitas pelayanan dan kepercayaan yang tinggi dapat mengubah pelanggan yang puas menjadi pelanggan yang setia.

Berdasarkan hasil analisis yang telah dilakukan hasil penelitian ini membuktikan bahwa

kualitas pelayanan dan kepercayaan memiliki prediksi terhadap kepuasan pelanggan karena pelanggan umumnya akan merasa senang dan puas atas pelayanan dan kepercayaan yang dapat bank berikan. Dengan perasaan puas atas pelayanan dan kepercayaan yang diberikan pelanggan akan menjadi pelanggan yang setia bagi perusahaan dan tetap menggunakan jasa dan membeli produk yang perusahaan sediakan sebagai pilihan utamanya.

\section{Saran}

Hasil penelitian ini diharapkan dapat menjadi pertimbangan dalam pengambilan keputusan bagi pihak perusahaan dan peneliti lain. Perusahaan dapat meningkatkan kualitas pelayanannya dengan memperhatikan setiap faktor yang mempengaruhinya. Perusahaan dapat memberikan pelayanan yang cepat dan dapat memecahkan setiap masalah yang dialami oleh konsumen secara efisien dengan cara yang ahli, dikarenakan melalui penelitian ini faktor tersebut memiliki kontribusi terbesar dalam kualitas pelayanan. Perusahaan dapat tetap memperhatikan keamanan transaksi yang dilakukan oleh pelanggan dan setiap janji perusahaan harus dapat diandalkan. Hal-hal tersebut dapat membuat perusahaan mempertahankan dan meningkatkan kepercayaan pelanggannya.

Bagi peneliti lain, disarankan agar jumlah pengambilan sampel dapat ditingkatkan dan jangkauan penelitian diperluas hingga Jabodetabek sehingga dapat mendapatkan data yang lebih akurat untuk penelitian selanjutnya. Dan juga disarankan untuk dapat menambahkan variabel-variabel lainnya seperti citra perusahaan, ikatan emosi, dan kemudahan.

\section{DAFTAR PUSTAKA}

Andreassen, T. W., \& Lindestad, B. (1998). Customer loyalty and complex service The impact of corporate image on quality, customer satisfaction and loyalty for 
customers with varying degrees of service expertise. International Journal of Service Industry Management, 9(1), 7-23. DOI: https://doi.org/10.1108/09564239810199923

Awan. H. M., Bukhari K. S., \& Iqbal. I. (2011). Service quality and customer satisfaction in the banking sector: A comparative study of conventional and Islamic banks in Pakistan. Journal of Islamic Marketing,2(3), 203-224. DOI:

Boonlertvanich. K. (2019) Service quality, satisfaction, trust, and loyalty: the moderating role of main-bank and wealth status. International Journal of Bank Marketing,37(1), 278-302. DOI: https://doi.org/10.1108/IJBM-02-2018-0021

Bouranta, N., Psomas, E., \& Vouzas, F. (2019). The effect of service recovery on customer loyalty: the role of perceived food safety. International Journal of Quality and Service Sciences, 11(1), 69-86. DOI: https://doi.org/10.1108/IJQSS-10-2017-0093

Chenet. P., Dagger. T. S. D., \& O'Sullivan. D. (2010). Service quality, trust, commitment and service differentiation in business relationships. Journal of Services Marketing,24(5), 336-346. DOI: https://doi.org/10.1108/08876041011060440

Cho, J. E., \& Hu, H. (2009). The effect of service quality on trust and commitment varying across generations. International Journal of Consumer Studies, 33, 468-476. DOI: https://doi.org/10.1111/j.1470-6431.2009.00777.x

Doney, P. M., Cannon, J. P., \& Mullen, M. R. (1998). Understanding the Influence of National Culture on the Development of Trust. The Academy of Management Review, 23(3), 601-620. DOI: https://doi.org/10.2307/259297

Eid. R. (2015). Integrating Muslim Customer Perceived Value, Satisfaction, Loyalty and Retention in the Tourism Industry: An empirical study. International Journal of Tourism Research, Int. J. Tourism Res.,17, 249-260. DOI: https://doi.org/10.1002/jtr.1982

Fatima. J. K., \& Razzaque. M. A. (2014). Roles of trust on rapport and satisfaction in services. Asia Pacific Journal of Marketing and Logistics,26(4), 566-578. DOI: https://doi.org/10.1108/APJML-01-2014-0013

Fauzi. A. A., \& Suryani. T. (2019). Measuring the effects of service quality by using CARTER model towards customer satisfaction, trust and loyalty in Indonesian Islamic banking. Journal of Islamic Marketing,10(1), 269-289. DOI: https://doi.org/10.1108/JIMA-04 2017-0048

Henseler, J., Ringle, C. M., \& Sinkovics, R. R. (2009). The Use of Partial Least Square Path Modeling in International Marketing. Advances in International Marketing, 20, 277319.

https://doi.org/10.1108/17590831111164750

Hur, W.-M., Park, J., \& Kim, M. (2010). The role of commitment on the customer benefits- loyalty relationship in mobile service industry. The Service Industries Journal, 30(14), 2293-2309.

Idun. A. A., \& Aboagye. A. Q.Q. (2014) Bank competition, financial innovations and economic growth in Ghana. African Journal of Economic and Management Studies,5(1):30-51. DOI: https://dx.doi.org/10.2139/ssrn.2199130

Johnson, M. D., Gustafsson, A., Andreassen, T. W., Lervik, L., \& Cha, J. 2001. Journal of Economic Psychology, 22(2001), 217-245.

Kotler, P., \& Armstrong, G. (2010). Principles of Marketing. Thirthteenth Edition. New Jersey:

Pearson Prentince Hall. 
Kundu. S., \& Datta. S. K. (2015) Impact of trust on the relationship of e-service quality and customer satisfaction. EuroMed Journal of Business,10(1), 21-46. DOI: https://doi.org/10.1108/EMJB-10-2013-0053

Lai, F., Griffin, M., \& Babin, B.J. (2009). How quality, value, image, and satisfaction create loyalty at a Chinese telecom. Journal of Business Research, 62(10):980-986. DOI: https://doi.org/10.1016/j.jbusres.2008.10.015

Liang, D., Ma, Z., \& Qi, L. (2013). Service quality and customer switching behavior in China's mobile phone service sector. Journal of Business Research,66(8), 11611167. DOI: https://doi.org/10.1016/j.jbusres.2012.03.012

Makanyeza, C., \& Chikazhe, L. (2017). Mediators of the relationship between service quality and customer loyalty: Evidence from the banking sector in Zimbabwe. International Journal of Bank Marketing, 35(3), 540-556 DOI: https://doi.org/10.1108/IJBM-11-2016-0164

Ndubisi. N. O. (2007). Relationship marketing and customer loyalty. Marketing Intelligence \& Planning, 25(1), 98-106. DOI: https://doi.org/10.1108/02634500710722425

Oliver, R. L. (1999). Whence Consumer Loyalty. Journal of Marketing Fundamental Issues and Directions for Marketing, 63, 33-44.

Orth. U. R., \& Green. M. T. (2009). Consumer loyalty to family versus non-family business: The roles of store image, trust and satisfaction. Journal of Retailing and Consumer $\quad$ Services, $16 . \quad 248-259 . \quad$ DOI: https://doi.org/10.1016/j.jretconser.2008.12.002

Parasuraman, A., Zeithaml, A.V., \& Berry, L.L. (1988). SERVQUAL: a multiple-item scale for measuring consumer perceptions of service quality. Journal of Retailing,64(1), 12-40.

Parasuraman, A., Zeithaml, V. A., \& Malhotra, A. (2005). A Multiple-Item Scale for Assessing Electronic Service Quality. Journal of Service Research, 7(3), 213-233.

Plasmeijer. P. W. J. V. E., \& Raaij. W. F. V. (2017). Banking system trust, bank trust, and bank loyalty. International Journal of Bank Marketing,35(1), 97-111. DOI: https://doi.org/10.1108/IJBM-12-2015-0195

Ram. J., \& Wu. M. L. (2016). A fresh look at the role of switching cost in influencing customer loyalty: Empirical investigation using structural equation modelling analysis. Asia Pacific Journal of Marketing and Logistics,28(4), 616-633. DOI: https://doi.org/10.1108/APJML-11-2015-0172

Saputra, R., \& Dewi, C. K. (2016). The impact of brand trust on brand loyalty mediated by customer satisfaction: Case of Tokobagus.com (now OLX.co.id). Journal of Administrative and Business Studies, 1(1), 8-13.

Shafei, I., \& Tabaa, H. (2016). Factors affecting customer loyalty for mobile telecommunication industry. EuroMed Journal of Business, 11(3), 347-361.

Sheng. T., \& Liu. C. (2010). An empirical study on the effect of e-service quality on online customer satisfaction and loyalty. Nankai Business Review International,1(3), 273283. DOI: https://doi.org/10.1108/20408741011069205

Solimun \& Fernandes, A. A. R. (2018). The Mediation Effect of Customer Satisfaction in the

Relationship Between Service Quality, Service Orientation, and Marketing Mix Strategy 
To Customer Loyalty. Journal of Management Development, 37(September 2018),76-87.

Spreng, R. A., \& Mackoy, R. D. (1996). An Empirical Examination of a Model of Perceived Service Quality and Satisfaction. Journal of Retailing, 72(2), 201-214. DOI: https://doi.org/10.1016/S0022-4359(96)90014-7

Stan, V., Caemmerer, B., \& Jallet, R. C. (2013). Customer Loyalty Develompment The Role Of Switching Costs. The Journal of Applied Business Research, 29(5), 15411554.

Yap. B. W., Ramayah. T., \& Shahidan. W. N. W. (2012). Satisfaction and trust on customer loyalty: a PLS approach. Business Strategy Series, 13(4),154-167. DOI: https://doi.org/10.1108/17515631211246221

Yunus, M., Ibrahim, M., \& Amir, F. (2018). The Role of Customer Satisfaction and Trust as

Mediation on The Influence of Service Quality and Corporate Image to Customer Loyalty. European Journal of Business and Management, 10(15), 121-129.

Zeithaml, V. A., Berry, L. L., \& Parasuraman, A. (1996). The Behavioral Consequences of Service Quality. Journal of Marketing, 60(April 1996), 31-46. 